\title{
Word Retrieval, Attention, and Inhibition under the Interference Condition for the 3rd-4th Grade Students with Specific Language Impairment
}

\author{
Yu Kyoung Janga, Soo Ryon Kim ${ }^{\mathrm{b}}$ \\ ${ }^{a}$ Graduate Program in Speech and Hearing Therapy, Graduate School of Catholic University of Pusan, Busan, Korea \\ ${ }^{b}$ Department of Speech and Language Pathology, Dankook University, Yongin, Korea
}

\author{
Correspondence: Soo Ryon Kim, PhD \\ Department of Speech and Language Pathology, \\ Dankook University, 152 Jukjeon-ro, Suji-gu, \\ Yongin 16890, Korea \\ Tel: $+82-31-8005-2276$ \\ Fax: +82-31-8021-7144 \\ E-mail: azzigom@naver.com
}

Received: October 5, 2019

Revised: November 13, 2019

Accepted: November 26, 2019

This work is based on the master's thesis of the first author.

\begin{abstract}
Objectives: This study was conducted to examine word retrieval in children with specific language impairment (SLI) under the interference condition; which is known to place a high burden on verbal processing. This study investigated whether reduced word retrieval can be explained in the aspect of attention and inhibition deficiency. Methods: The participants were a total of 30 elementary school students in 3rd-4th grades, including 15 children with SLI and 15 typically developing (TD) children. A word retrieval task under an interference condition, an attention task (rapid automatized naming, RAN), a nonverbal inhibition task (Go-No-Go task), and a verbal inhibition task (STROOP Color and Word Test) were used as the experimental tasks. Accuracy, response time of word retrieval under the interference conditions, attention, and nonverbal and verbal inhibition abilities between groups were compared. Results: The children with SLI had significantly longer response time in word retrieval under the interference condition. Error analysis results showed difficulty in inhibiting unrelated words as well as interference words. Also, color RAN, object RAN and verbal inhibition, which required high levels of attention and language processing, were significantly lower than those of normal children. In the SLI group, the word retrieval response time showed a significant correlation with the response time of color and object RAN. Conclusion: Children with SLI showed a limitation in inhibiting interference stimuli and paying attention to target stimuli for semantic processing. Therefore, when treating vocabulary learning and word retrieval in children with SLI, a cognitive approach should be considered.
\end{abstract}

Keywords: School-aged, Specific language impairment, Interference condition, Word retrieval, Attention, Inhibition
사람들은 자신의 생각을 말로 표현하며 타인과 의사소통을 하 는데 이때, 전달하려는 메시지의 내용을 구성하기 위해 적절한 단 어들을 효율적으로 인출할 수 있어야 한다. 단어인출이 원활하게 이루어지려면 의미망 내에 저장된 어휘의 양과 어휘처리 능력이 충 분히 마련되어 있어야 한다. 일반적으로 아동은 연령이 증가함에 따라 새로운 어휘를 습득하여 어휘집에 저장하고 저장된 어휘는 의미를 확장해 나간다. 그리고 필요한 상황에서 적절한 단어를 인 출하여 산출할 수 있게 된다(Lee \& Ha, 2015). 학령기가 되었을 때 는 더 많은 어휘들을 의미에 근거해 조직화하게 되고 특정 상황에
서 쉽게 낱말 찾기가 이루어져 단어를 빠르게 인출해 낼 수 있게 된 다(Gleason, 2005; Kim, 2005; Long \& Long, 2005; Pae, 2005; Paul, 2003, 2007).

단순언어장애 아동은 첫 낱말 산출이 늦고 이후 새로운 어휘를 습득하여 의미를 확장해 가는 과정에서 일반아동보다 느린 속도를 보인다. 결국 저장하고 있는 어휘의 양이 적고 어휘집 내에서 어휘 들 간의 연결망 형성이 충분치 않아 낱말찾기장애(word finding disorder)가 발생하게 되는데 이것은 단어인출의 실패로 이어지게 된다(Leonard, 1998). 이들은 학령기가 되어서도 지속적인 어휘 저 
장 및 처리 능력의 부족으로 인해 어휘와 의미적으로 관련된 정보 를 찾아내는데 실패하여 단어인출의 정확성과 속도에서 결함을 보 이게 된다(Kail \& Salthouse, 1994; McGregor, 1994; McGregor \& Leonard, 1989).

일부 연구에서는 단순언어장애 아동의 부족한 단어인출 능력에 대해 어휘처리과정 중에 발생한 오류로 설명하였다(Lahey \& Edwards, 1999; Lee \& Kim, 2002). Levelt, Roelofs와 Meyer (1999)의 어휘처리과정 모델을 근거로 하여 일차적으로는 어휘의 의미 처리 단계(lemma)에서의 문제라고 논의하였고 이 단계에서 어휘를 의미 기억 속에 저장할 때 관련 어휘들과 충분히 연결망을 형성하지 못 한 상태로 저장하였기 때문에 오류를 보이는 것이라고 하였다. 그리 고 해당 어휘에 대한 적절한 음운형태를 선택하지 못하였을 경우 다시 의미적 단계로 돌아가서 의미적으로 유사한 다른 어휘를 선택 하여 산출하게 된다는 것이다(Lee \& Kim, 2002). 즉, 단순언어장애 아동은 어휘처리과정에서 목표 어휘에 대한 접근이 활성화 되지 않 아 정확하고 빠르게 인출해 내는데 어려움을 보인다는 것이다.

이름대기 과제를 실시하여 단순언어장애 아동의 단어인출 결함 에 대해 살펴본 연구로 Fried-Oken (1984)은 4-9세의 단순언어장 애 아동의 단어인출 능력을 살펴보았다. 그 결과, 단순언어장애 아 동이 일반아동보다 정확도는 낮았고 반응시간은 더 긴 것으로 나 타났다. Lee와 Kim (2003)은 4-6세 단순언어장애 아동을 대상으 로 이해하고 있는 단어에서의 단어인출 특성을 살펴보고자 연구를 실시하였다. 단순언어장애 아동이 이름대기 과제에서 오반응한 문 항에 대하여 낱말이해 과제를 실시하였는데, 만약 아동이 낱말이 해 과제는 정확히 수행하였으나 이름대기 과제에서 오류를 보인다 면 본인이 알고 있는 낱말임에도 불구하고 단어인출의 실패로 인해 오류를 보인다고 가정하였다(German, 1994, 2000). 그 결과, 단순 언어장애 아동은 자신이 알고 있는 단어조차 인출하는데 어려움 을 보였다. 이러한 선행연구들을 통해 단순언어장애 아동은 어휘집 에 접근하고 인출하는 어휘처리과정에서 결함이 있어 의도하는 단 어를 정확하고 빠르게 산출하는데 실패하는 결과를 낳게 된다.

단순언어장애 아동의 어휘처리과정 중의 실패와 관련하여 Kail 과 Salthouse (1994)는 단순언어장애 아동의 언어적 결함 원인이 정 보처리과정에서 문제라는 가능성을 제기하였는데, 단순언어장애 아동은 정보처리과정에서 공간(space), 시간(time), 효율성(energy) 측면에서 어려움을 보인다고 밝혔다. 이로 인해 단순언어장애 아동 은 저장할 수 있는 공간이 작아 정보를 많이 저장하는데 한계가 있 고 입력되는 정보들도 빠르게 처리되지 못하거나 제한된 시간 내에 정확하게 처리되지 못하여 특정 과제를 제대로 완료하지 못하게 된 다. 특히, 처리해야 할 정보들이 지속적으로 제시되는 상황에서 시
간적 정보처리(temporal processing) 능력은 중요하게 작용하며 아 동의 빠른 처리 속도는 성공적인 과제 수행에 중요한 요소로 볼 수 있다. 하지만 단순언어장애 아동은 일반아동에 비해 역동적인 처 리 능력이 부족한 것으로 나타났다(Visto, Cranford, \& Scudder, 1996).

전반적인 처리 능력의 제한과 관련하여 최근 단순언어장애 아동 에게서 주의집중 능력에 결함이 있다고 보고되기도 하였다(Dodwell \& Bavin, 2008; Spaulding, Plante, \& Vance, 2008). 단순히 언어적 측면뿐만 아니라 주의집중 문제를 살펴볼 수 있는 유용한 지표로 빠른이름대기(rapid automatized naming, RAN)가 있다(Plaza \& Cohen, 2005; Waber, Wolff, Forbes, \& Wieler, 2000). 빠른이름대 기는 친숙한 시각적 자극(숫자, 글자, 사물, 색깔 등)을 최대한 빨리 산출하는 것으로(Denckla \& Rudel, 1976) 목표 자극과 관련된 정 보를 처리하는 과정에서 주의력이 요구된다(Wolf \& Bowers, 1999). 연구자들은 숫자 빠른이름대기와 글자 빠른이름대기를 자 동화된 과제, 색깔 빠른이름대기와 사물 빠른이름대기를 덜 자동 화된 과제라고 분류하였다(Hogan-Brown, Hoedemaker, Gordon, \& Losh, 2014). 숫자 및 글자 빠른이름대기에서는 숫자와 글자 상징 에 대한 자동적인 처리가 이루어지는 반면, 색깔 및 사물 빠른이름 대기는 자극에 대한 의미적인 처리과정이 요구되기 때문이다. 이 때, 목표 자극에 대한 효율적인 언어적 접근이 이루어지기 위해서 는 해당 자극에 주의를 기울이고 다음 자극으로 주의를 전환하며 과제 전반에 걸쳐 지속적인 주의력을 유지해야 한다.

이와 관련하여 단순언어장애 아동을 대상으로 선택적 주의를 시행하며 장기기억에서 활성화된 정보를 유지 및 조작하는 기능을 하는 중앙집행(central executive)에 대한 연구들도 있다(Baddeley, 1983, 1986). 특히, 중앙 집행에 포함되는 기제인 '억제(inhibition)' 는 관련 없는 자극을 무시하고 조절할 수 있도록 하는 것인데, 단순 언어장애 아동의 억제 능력이 일반아동보다 낮은 수행력을 보인다 고 보고되었다(Henry \& Winfield, 2010; Spaulding, 2010). 단순언 어장애 아동은 부족한 억제 능력으로 인해 방해되는 정보를 통제 하고 규칙에 따라 필요한 정보만을 선택하는 것에서 결함을 보이게 된다(Im-Bolter, Johnson, \& Pascual-Leone, 2006). Stevens, Sanders와 Neville (2006)은 단순언어장애 아동과 일반아동의 선택적 청각적 주의력의 초기 매커니즘을 비교하기 위해 사건관련전위 (event-related potential, ERP)를 사용하였다. 그 결과, 단순언어장 애 아동이 도움이 되는 자극은 받아들이고 관련 없는 자극을 억제 하는데 취약함을 보였다. Bishop과 Norbury (2005)는 단순언어장 애 아동의 억제 능력을 측정하고자 구두 반응이 요구되는 과제와 행동적 반응이 요구되는 과제를 실시하여 억제 능력을 측정하였고 
이들은 언어적 억제 능력과 비언어적 억제 능력 모두 일반아동보다 부족하다고 논의하였다. 이와 같이 단순언어장애 아동이 보이는 언 어적 결함의 원인에 대해 인지적 처리과정에서의 문제로 논의되는 연구들이 진행되어 왔다. Swisher, Plants와 Lowell (1994)에 따르면 단순언어장애 아동은 언어적 처리 능력과 비언어적 처리 능력에 잠 재적인 결함을 가질 가능성이 있다고 하였는데, 언어적 정보뿐만 아 니라 비언어적 정보를 처리하는 능력 또한 언어적 성과에 중요한 역 할을 한다면(Pisoni, Kronenberger, Roman, \& Geers, 2011) 단순언 어장애 아동이 억제 과제의 유형에 따라 언어적 및 비언어적 억제 과제에서 일반아동과 어떠한 차이를 보이는지 알아볼 필요가 있다.

위에서 살펴본 주의력과 억제 능력은 어휘 학습에 필수적인 기제 이다. 필요한 정보만을 선택하여 집중하고 관련 없는 자극을 억제 하는데 성공한다면 목표 자극을 효율적으로 처리할 수 있게 되어 어휘 학습에서 매우 중요한 역할을 하게 된다. 그러나 방해 자극을 제시하여 처리 속도를 늦추고 집중력을 분산시키는 기제인 '간섭 (interference)'은 언어적 처리를 요하는 과정에서 항상 존재한다. 간 섭 자극에 대한 억제가 성공적으로 이루어진다면 이미 부호화된 관련 없는 정보를 능동적으로 억누를 수 있게 되면서 언어적 처리 가 원활하게 이루어지게 된다(Wilson \& Kipp, 1998). 간섭 과제는 어휘 접근 과정의 특성을 분석할 수 있고 목표 반응에 대한 간섭을 일으켰을 때 나타나는 간섭에 대한 반응의 양상을 살펴볼 수 있다 (Kim, Choi, \& Hwang, 2016). 단순언어장애 아동에게 간섭 과제를 실시한 연구로, Seiger-Gardner와 Schwartz (2008)는 8-10세의 단 순언어장애 아동을 대상으로 다양한 시점(그림 제시 전, 그림 제시 와 동시에, 그림 제시 이후)에 그림(목표 단어)과 함께 간섭 단어를 구어로 제시하여 아동에게 들리는 간섭 단어를 무시하고 그림에 해당하는 단어를 산출하도록 하였다. 그 결과, 그림과 의미적으로 관련된 단어가 미리 제시되었을 때 이름대기 속도가 느려져 간섭 효과가 나타났다. 의미적으로 관련된 단어가 이름대기 수행에 미치 는 간섭 효과는 단순언어장애 아동이 의미 정보를 처리하는데 어 려움이 있음을 나타낸다. 국내연구에서도 단순언어장애 아동을 대 상으로간섭 효과에 대한 연구가 진행되었다. Yang, Yim과 Bae (2015) 는 1-3학년 단순언어장애 아동을 대상으로 그림-단어 간 간섭효과 가 나타나는지 알아보고자 그림과 함께 글자로 동일한 단어, 반의 어 관계의 단어, 관련 없는 단어를 제시하고 아동에게 그림과 반의 어 관계의 단어를 세 가지 보기 중에서 선택하게 하여 정확도와 반 응시간을 측정하였다. 그 결과, 단순언어장애 아동은 일반아동보 다 정확도가 낮았고 반응시간이 느렸다. 즉, 목표 단어로 접근할 때 방해하는 정보들을 억누르는데 실패하게 되어 오반응과 함께 지연 된 반응시간을 보이는 것으로 나타났다.
현재까지 단순언어장애 아동을 대상으로 인지적 처리가 요구되 는 다양한 비언어적 과제(작업기억, 억제 조절 등)를 실시하여 전반 적인 언어 능력, 어휘력 등과 같은 광범위한 언어적 수행과의 상관 을 입증해왔다. 주의, 억제 등과 같은 정보처리 능력은 단순언어장 애 아동의 단어인출 능력을 면밀히 살펴볼 수 있는 요소이고 단순 언어장애 아동이 해당 어휘에 접근하고 처리할 때 어떠한 양상을 보이는지 확인할 수 있는 유용한 근거가 될 수 있다. 언어를 처리할 때는 억제할 정보와 처리할 정보를 구분하는 능력이 갖춰져야 한 다. 특히, 어휘처리 능력이 어느 정도 발달된 시기인 학령기에는 이 러한 능력이 매우 중요하다고 볼 수 있다. 현재까지 학령기 단순언 어장애 아동을 대상으로 단어인출의 접근 및 처리 과정에 대해 살 펴본 연구는 부족한 실정이다. 따라서 본 연구에서는 어휘처리과정 에서 지속적으로 어려움을 보이는 학령기 단순언어장애 아동을 대상으로 간섭 조건에서의 단어인출 능력을 살펴보고자 하였고 이 들의 단어인출 효율의 저하를 주의력과 비언어적 억제 능력, 언어 적 억제 능력의 부족으로 설명할 수 있는지 알아보고자 한다. 이에 대한 세부적인 연구문제는 다음과 같다.

첫째, 집단 간(단순언어장애 아동, 일반아동) 간섭 조건의 단어 인출 과제에서 정확도와 반응시간에 차이가 있는가? 그리고 두 집 단은 오류유형에서 차이가 있는가?

둘째, 집단 간(단순언어장애 아동, 일반아동) 주의력 과제에서 반응시간에 차이가 있는가?

셋째, 집단 간(단순언어장애 아동, 일반아동) 비언어적 억제 과제 에서 정확도에 차이가 있는가?

넷째, 집단 간(단순언어장애 아동, 일반아동) 언어적 억제 과제에 서 정확도에 차이가 있는가?

다섯째, 각 집단(단순언어장애 아동, 일반아동)에서 단어인출 과 제의 정확도 및 반응시간, 주의력 과제의 반응시간, 비언어적 억제 과제의 정확도, 언어적 억제 과제의 정확도 간에 상관관계가 있는가?

\section{연구방법}

\section{연구대상}

본 연구대상은 부산 및 울산 지역의 초등학교 3-4학년에 재학 중 인 아동들이었다. 본 연구의 실험 과제는 대상 아동에게 제시된 그 림과 반의어 관계에 있는 단어를 읽도록 요구하는 것이므로 자신 이 습득한 철자 지식과 음운규칙을 적용하여 단어를 유창하게 읽 을 수 있는 시기인 만 7-9세 즉, 초등학교 3-4학년의 아동을 대상으 로 하였다. 그리고 단순언어장애 아동 15명(3학년 9명, 4학년 6명), 일반아동 15명(3학년 7명, 4학년 8명)으로 총 30명을 대상으로 실 
시하였다. 대상자 선별을 위해 한국 비언어성 지능검사(Korean version of Comprehensive Test of Nonverbal Intelligence-2, K-CTONI-2; Park, 2014)와 수용 및 표현어휘력검사(Receptive and Expressive Vocabulary Test, REVT; Kim, Hong, Kim, Jang, \& Lee, 2009) 를 실시하였다. 그리고 실험 과제에서 제시되는 수준의 단어를 읽 을 수 있는지 확인하기 위해 Kim (2009), Choi (2014)의 연구를 근 거로 초등 저학년 수준의 단어들을 선정하여 직접 제작한 단어 읽 기 선별 과제를 실시하였다.

단순언어장애 아동은 Leonard (1998)의 기준에 따라 다음과 같 이 선정하였다. (1) 부모와 교사에 의해 지적 능력은 정상 범주이지 만 언어 능력이 부족하다고 보고된 아동으로, (2) 한국 비언어성 지 능검사(K-CTONI-2)에서 도형척도의 지능지수가 85 이상으로 정 상 범위에 속하면서, (3) 수용 및 표현어휘력검사(REVT) 결과, 수 용 및 표현어휘력의 점수가 하나 혹은 둘 다에서 본인의 생활연령 기준으로 $10 \% \mathrm{ile}$ 이하에 속하고, (4) 시각과 청각 등에서 결함과 정 서 및 행동 문제를 보이지 않는 아동이며, (5) 단어 읽기 선별 과제에 서 제시하는 단어를 모두 읽을 수 있는 아동으로 선정하였다.

일반아동은 (1) 부모와 교사에 의해 지적 능력이나 언어 능력이 정상으로 보고된 아동으로, (2) 한국 비언어성 지능검사(K-CTO$\mathrm{NI}-2$ )에서 도형척도의 지능지수가 85 이상으로 정상 범위에 속하 면서, (3) 수용 및 표현어휘력검사(REVT) 결과, 수용 및 표현어휘력 의 점수가 모두 정상 범위(-1 SD 이상)에 속하고, (4) 시각과 청각 등 에서 결함과 정서 및 행동 문제를 보이지 않는 아동이며, (5) 단어 읽기 선별 과제에서 제시하는 단어를 모두 읽을 수 있는 아동으로 선정하였다.

두 집단에 대한 통제가 잘 이루어졌는지 알아보기 위하여 독립 표본 $t$-검정을 실시하였다. 그 결과, 수용어휘력에 대한 집단 간 유 의한 차이가 있었고, 표현어휘력 역시 집단 간 유의한 차이가 있었 다. 그 외 비언어성 지능과 단어 읽기 선별 과제의 점수는 집단 간에 유의한 차이가 없었다(Table 1).

\section{연구도구}

\section{간섭 조건의 단어인출 과제}

목표 단어를 인출하기 위해 어휘집에 접근하는 능력과 방해 자 극을 억제하는 능력이 단어인출 수행력에 어떠한 영향을 주는지 확인하기 위해 간섭 조건의 단어인출 과제를 실시하였다. 실험 과제 는 그림과 동일한 단어인 간섭 자극을 효율적으로 억제할 수 있는 지 살펴본 Yang 등(2015)의 연구 과제를 수정·보완하였다. 실험 과 제에 사용된 단어는 Yang 등(2015)의 연구에서 사용된 단어를 기 반으로 하였고 그 중 국립국어원에서 발간한 “초등학교 교과서 어
Table 1. Participants' characteristics

\begin{tabular}{lccc}
\hline Characteristic & SLI $(\mathrm{N}=15)$ & $\mathrm{NL}(\mathrm{N}=15)$ & $t$ \\
\hline Nonverbal IO $\mathrm{O}^{\mathrm{a}}$ & $105.87(9.797)$ & $110.80(9.872)$ & -1.374 \\
Receptive vocabulary $^{\mathrm{b}}$ & $89.93(11.877)$ & $118.00(17.760)$ & $-5.088^{*}$ \\
Expressive vocabulary $^{\mathrm{b}}$ & $80.47(10.385)$ & $114.00(19.116)$ & $-5.970^{*}$ \\
Word reading $^{\mathrm{c}}$ & $25.00(0.000)$ & $25.00(0.000)$ & \\
\hline
\end{tabular}

Values are presented as mean (SD).

$\mathrm{SLI}=$ children with specific language impairment; $\mathrm{NL}=$ normal language children . aKorean Comprehensive Test of Nonverbal Intelligence-2 (Park, 2014), ${ }^{\text {b } R e c e p t i v e ~ \& ~}$ Expressive Vocabulary Test (Kim, Hong, Kim, Jang, \& Lee, 2009), 'Word Reading Screening Test.

${ }^{*} p<.05$.

휘 조사 연구(Kim, 2009)"를 참고하여 저학년 교과서에서 사용된 단어들 중 명사만을 선정하였다. 특히, 비관련 단어를 선정할 때 의 미적, 음운적으로 비슷한 단어를 구성하는데 어려움이 있으므로 동일한 음절로 끝나는 반의어 관계의 단어(예: '남자-여자')를 제외 하였다. 그리고 비관련 단어는 반의어 관계의 단어와 비슷한 의미 범주인 인물, 공간, 도형, 신체 등에 속하며(예: 오-엑스-세모') 음운 적 특징이 완전히 다르지 않는 단어들로 선정하였다(예: 물-불-돌'). 그 결과, 연습 문항 4 개, 본 문항 20 개로 총 24 문항이 구성되었다. 과 제에서 사용된 단어목록은 Appendix 1에 제시하였다.

아동에게 제시되는 자극은 하나의 그림 자극(예: 4)과 함께 글자 자극으로 (1) 그림 자극에 해당하는 단어(예: 위), (2) 그림과 반의어 관계의 단어(예: 아래), (3) 그림과 관련 없는 단어(예: 어디) 세 가지 를 제시하였고 이 때, 아동에게 간섭 단어(예: 위)를 억제시키고 목 표 단어인 그림과 반의어 관계의 단어(예: 아래)를 읽게 하였다.

실험 과제는 노트북 화면 상단에 그림 자극을 제시하고 하단에 는 보기 세 개의 글자 자극을 제시하였다. Office의 Power Point 프 로그램을 활용하여 자극 화면은 검은 바탕에 흰색 글씨로 제시하 였다. Kim 등(2016)에 따르면 흰 바탕에 검은 선화보다는 검은 바 탕에 흰 선화에서 확실한 간섭효과가 나타났다고 한다. 그림 자극 의 크기는 가로와 세로 10-12 cm로 지정하였다. 그러나 ‘흐림', ‘바 다' 등과 같이 전체적인 배경이 중요한 자극의 경우 상단을 배경 그 림으로 채워서 설정하였다. 화면 하단에 제시되는 글자 자극은 맑 은 고딕체로 크기는 $8 \mathrm{pt}$ 였다(Appendix 2). 각 문항이 제시될 때, 아 동이 단어를 산출하면 검사자가 노트북의 키보드를 눌러 화면이 다음 문항으로 전환되게 하였다. 모든 자극은 1 회만 제시되고 글자 자극의 유형은 무선배열로 제시되었다.

\section{주의력 과제}

언어적 정보처리에서 요구되는 주의력을 살펴보기 위해 빠른이 름대기(RAN)를 실시하였다. 본 연구에서는 Park (2009)의 연구에 
서 사용된 빠른이름대기 과제를 수정·보완하였다. Park (2009)의 낱자 빠른이름대기로 예비 실험을 실시하였을 때 낱자 / ㄱ/를 '기 역’으로 읽는 문제점이 확인되어 글자 빠른이름대기로 진행하였다. 글자 빠른이름대기는 연구대상의 학년이 3-4학년임을 고려하여 Park (2009)의 연구를 참고해서 가장 빈번하게 사용되는 낱자 ' $ᄀ$,

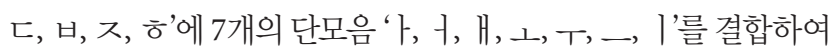
다양한 자모음 조합의 글자로 제작하였다. 그리하여 본 연구에서는 숫자, 글자, 색깔, 사물 빠른이름대기로 제작하였고 숫자, 글자, 색 깔, 사물 자극이 5 개씩 배열된 연습 문항과 각 자극을 가로 10 열, 세 로 5 줄로 총 50 개씩 배열된 본 문항을 구성하였다. 아동에게 각 자 극(숫자, 글자, 색깔, 사물)이 제시된 화면을 보여주며 최대한 빠르 게 말해달라고 요청하였다.

\section{비언어적 및 언어적 억제 과제}

비언어적 억제 능력을 살펴보기 위해 고노고 과제(Go-No-Go task)를 실시하였다. 고노고 과제는 계속적으로 하던 행동 반응을 멈추고 반응 자체를 하지 않아야 하는, 즉 반응 억제가 요구된다 (Hwang et al., 2016). 본 연구에서는 Go-No-Go 과제의 기존 원리 를 바탕으로 도형을 이용하여 고노고 과제를 실시하였다. 연습 문 항 5 개와 본 문항 50 개를 구성하여 검사자는 아동에게 노란색 동그 라미가 나타나면 책상을 치고 초록색 동그라미가 나타나면 가만히 있도록 지시하였다. 고노고 과제의 자극은 노트북 화면에 노란색 동그라미와 초록색 동그라미 50개가 무작위로 제시되고 화면이 자 동으로 넘어가도록 구성하였다. 목표 자극과 방해 자극을 1.5 초 동 안 제시하고 자극 간에 0.5 초 동안의 휴지기가 있도록 설정한 선행 연구(Jin, Lee, \& Hong, 2007)와 동일하게 각 자극(노란색 동그라 미, 초록색 동그라미)이 노출되는 시간은 1.5 초로 설정하였고 각 자 극이 제시되는 사이에 휴지기를 0.5 초로 설정하였으며 이때, 검정 색 화면이 나타나도록 하였다. 즉, 아동에게 동그라미 자극이 1.5초 동안 제시되고 그 다음 휴지기에 검정색 화면이 0.5 초 동안 나타나 며 또 다시 동그라미 자극이 1.5 초 동안 제시된다.

언어적 억제 능력을 살펴보기 위해 스트룹 아동 색상-단어 검사 (Stroop Color And Word Test; Shin \& Park, 2007)를 실시하였다. 주어지는 자극의 특성 중 일부가 목표 반응을 방해하도록 고안되 어 있고 올바른 반응을 하기 위해 방해 자극의 간섭을 억제하는 능 력과 주의의 통제 능력을 측정할 수 있다(Hwang et al., 2016). 본 연 구에서는 단어, 색상, 색상-단어의 세 개의 기본 과제를 제시하였고 한 가지 과제 당 45 초 동안 실시하였다. 특히, 색상-단어 과제는 언 어적 억제 과제로 색상과 단어가 일치하지 않는 조건에서 단어 자 극을 무시하고 색상을 말해야 하는 과제이다(Shin \& Park, 2007).
예를 들어, 파란색으로 인쇄된 ‘빨간색’이라는 글자를 글자의 잉크 색인 “파란색”으로 말해야 하는 과제이다.

\section{타당도}

간섭 조건의 단어인출 과제에서 사용된 단어 목록과 그림 자료 가 간섭 자극을 억제하여 목표 단어로 접근하는 능력을 살펴보기 위한 측정치로 적절한가에 대해 2 명의 전문가에게 내용타당도를 검증하였다. 2 명의 전문가는 언어재활사 1 급 자격증과 박사학위 소 지자이다. 2 명의 전문가는 반의어 관계의 단어, 해당 단어를 나타내 는 그림 자료에 대한 적절성을 5 점 척도로 평가하여 그 결과, 반의 어 관계의 단어에 대한 타당도는 4.76 , 그림 자료에 대한 타당도는 4.58 로 높은 타당도를 검증받았다.

\section{연구절차}

각 실험 과제의 자극이 제시되는 시간, 문항수, 단어 목록이 아 동들에게 적절한지 확인하기 위해 초등학교 3학년 학령기 단순언 어장애 아동 1 명과 일반아동 1 명을 대상으로 예비 실험을 실시하 였다. 예비 실험을 통해 검사 실시 순서, 검사 항목, 단어 목록 등을 수정·보완한 후 본 실험을 실시하였다.

실험 과제 특성상 아동의 처리 능력에 대한 순수한 반응을 이끌 어내기 위해 각 과제를 1 회만 실시해야 하므로 아동이 본 실험에만 집중할 수 있도록 소음을 최소화하거나 방해 받지 않는 공간에서 실시하였다. 또한 검사자와 아동은 노트북을 함께 보며 나란히 앉 아 1:1로 진행되었다. 먼저 선별 검사를 실시한 후, 실험 과제인 간섭 조건의 단어인출 과제, 주의력 과제(빠른이름대기 과제), 비언어적 억제 과제(고노고 과제), 언어적 억제 과제(스트룹 아동 색상-단어 검사)를 실시하였다.

간섭 조건의 단어인출 과제는 연습 문항을 제시하면서 "선생님 이랑 단어 맞추기 놀이해봐요. 세 개의 단어 중에 이 그림이랑 반대 되는 단어를 찾아서 읽어주면 돼요.”라고 설명하였다. 이때, 아동의 어휘 접근 능력을 정확하게 측정하기 위해 최대한 빠르게 반응할 것을 지시하면서 아동의 정확도와 반응시간이 기록되도록 하였다. 먼저 연습 문항 4 개를 실시한 후에 아동에게 단어를 가리키는 것이 아니라 단어를 읽어야 한다고 한번 더 지시하고 나서 본 문항을 실 시하였다.

빠른이름대기 과제는 연습 문항을 제시하며 아동에게 "이제 선 생님이 보여주는 것을 최대한 빠르게 말해주세요"라고 설명하였고 사물 빠른이름대기의 경우 익숙하지 않은 그림 자극으로 인해 아 동이 그림의 이름을 잘못 말할 경우 검사자는 정확한 이름을 다시 들려주었다. 그리고 본 문항 시작 전에 “선생님이 '시작'이라고 말하 
면 처음부터 마지막까지 빠르게 말해주세요.”라고 지시하였다.

고노고 과제는 아동에게 “이 컴퓨터 화면에 동그라미가 계속해 서 나타날 거예요. 노란색 동그라미가 나타나면 책상을 치고 초록 색 동그라미가 나타나면 가만히 있으면 돼요.”라고 지시하였고 연 습 문항을 실시하여 실시 방법에 대한 이해가 충분히 이루어진 후 본 문항을 실시하였다.

스트룹 아동 색상-단어 검사는 단어, 색상, 색상단어 과제를 모두 실시하였는데 색상단어 과제의 경우 아동에게 “여기를 보면 글자 는 빨간색이라고 적혀져 있지만 색깔은 파란색이에요. 글자를 읽으 면 안 되고 무슨 색깔인지를 말해줘야 해요.”라고 말하며 “선생님 이 '그만'이라고 말하면 거기까지 말해주면 돼요”라고 지시하였다.

각 실험 과제에서 정확도와 반응시간을 측정하기 위해 아동의 모든 반응은 녹음하여 파일로 저장되었다. 과제에 대한 아동의 반 응은 실시하는 동안 기록하였으며 정확한 분석을 위해 녹음 결과 와함께 비교하면서 결과 분석에 신뢰도를 높일 수 있도록 하였다.

\section{자료분석}

간섭 조건의 단어인출 과제는 정확도와 반응시간을 분석하였다. 정확도는 정반응한 경우 1 점, 오반응한 경우 0 점으로 계산하고, 정 반응한 문항의 총 개수가 해당 과제의 정확도로 측정되었다. 아동 이 오류를 보였다가 자가수정 하더라도 첫반응으로 오류를 보인 단 어를 억제하는데 실패한 것으로 보고 그 문항은 오반응으로 처리 하였다. 반응시간은 음성파일에서 자극이 제시되는 순간부터 단어 를 산출하기까지의 시간을 $\mathrm{ms}(1 / 1,000 \mathrm{~s})$ 단위로 Praat (음성 분석 프로그램)을 이용하여 측정하였고 이를 초 단위로 다시 계산하였 다. 단, 아동이 정반응을 보인 반응시간만 분석에 포함하고, 반응시 간이 $100 \mathrm{~ms}$ 미만인 경우는 과제를 정확히 인지하여 단어인출을 했다고 보기 어려울 만큼 짧은 시간이므로 분석에서 제외하였다 (Kail \& Salthouse, 1994). 즉, 반응시간은 총 정반응 시간의 합을 정 반응 개수로 나누어 평균을 산출하였다. 오류유형은 오반응을 간 섭 단어(그림과 동일한 단어)와 비관련 단어(그림과 관련 없는 단 어)로 분류하여 산출한 빈도를 측정하였다. 간섭 단어를 산출한 비 율은 간섭 단어 오류 개수를 총 오반응 문항의 개수로 나누어 100 을 곱하여 계산하였다. 비관련 단어를 산출한 비율은 비관련 단어 오류 개수를 총 오반응 문항의 개수로 나누어 100 을 곱하여 계산 하였다.

주의력 과제(빠른이름대기 과제)는 첫 자극을 말하기 시작한 시 간부터 마지막 자극을 말한 시간까지 초 단위로 측정하여 반응시 간을 계산하였다.

비언어적 억제 과제(고노고 과제)는 자극 수가 50개이므로 50점
을 총점으로 하여 정반응은 1 점, 오반응 또는 무반응은 0 점으로 계 산하였다.

언어적 억제 과제(스트룹 아동 색상-단어 검사)는 단어 점수, 색 상 점수, 색상단어 점수, 간섭 점수가 산출된다. 단어, 색상, 색상-단 어는 원점수를 산출한 후, 색상 원점수에서 색상단어 원점수를 빼 서 간섭 원점수를 산출하였다. 그리고 하위검사의 원점수를 연령 규준에 따라 $\mathrm{T}$ 점수로 변환하였다. 본 연구에서는 간섭 $\mathrm{T}$ 점수를 분 석 자료로 사용하여 아동의 억제 능력을 살펴보았다. 간섭 $\mathrm{T}$ 점수 가 높다는 것은 과도한 간섭이 일어났다는 것으로 해석될 수 있다.

\section{신뢰도}

간섭 조건의 단어인출 과제, 주의력 과제, 비언어적 억제 과제, 언 어적 억제 과제에 대한 신뢰도를 검증하기 위해 수집된 자료의 $20 \%$ 를 임의로 선정하여 평가자 간 신뢰도를 산출하였다. 평가자로 언 어재활사 2 급 자격증을 소지한 2 명의 대학원생이 참여하였고 연구 자는 평가자에게 검사 방법, 기록, 채점 방법에 대해 설명한 후 채점 하도록 하였다. 간섭 조건의 단어인출 과제에 대한 평가자 간 신뢰 도는 $97.4 \%$ 로 나타났다. 주의력 과제에 대한 평가자 간 신뢰도는 숫 자 빠른이름대기 $98.9 \%$, 글자 빠른이름대기 $98.5 \%$, 색깔 빠른이름 대기 $98 \%$, 사물 빠른이름대기 $97.8 \%$ 로 나타났다. 두 억제 과제에 대한 평가자 간 신뢰도는 고노고 과제 $100 \%$, 스트룹 아동 색상-단 어 검사 $99 \%$ 로 나타났다.

\section{통계분석}

첫째, 두 집단 간 간섭 조건의 단어인출 과제에서 정확도와 반응 시간의 차이를 살펴보기 위해 독립표본 $t$-검정을 실시하였고 오류 유형의 특성을 알아보기 위해 기술통계를 실시하였다. 둘째, 두 집 단 간 주의력 과제에서 반응시간의 차이를 살펴보기 위해 독립표 본 $t$-검정을 실시하였다. 셋째, 두 집단 간 비언어적 억제 과제와 언 어적 억제 과제에서 정확도의 차이를 살펴보기 위해 독립표본 $t$-검 정을 실시하였다. 넷째, 각 집단에서 간섭 조건의 단어인출 과제 정 확도 및 반응시간, 주의력 과제 반응시간, 비언어적 억제 과제의 정 확도, 언어적 억제 과제의 정확도 간에 상관관계가 있는지 알아보 기 위해 Pearson 상관을 실시하였다.

\section{연구결과}

\section{집단 간(단순언어장애 아동, 일반아동) 간섭 조건에서의 단어인출 능력 비교}

먼저, 단순언어장애 아동과 일반아동 간 간섭 조건에서 단어인 
출 정확도를 비교한 결과, 단순언어장애 아동은 일반아동보다 낮 은 점수를 보였다. 독립표본 $t$-검정을 실시한 결과, 두 집단 간 정확 도에 유의한 차이가 있었다. 다음으로 단순언어장애 아동과 일반 아동 간 간섭 조건에서 단어인출 반응시간을 비교한 결과, 단순언 어장애 아동은 일반아동보다 느린 반응시간을 보였다. 독립표본 $t$ 검정을 실시한 결과, 두 집단 간 반응시간에 유의한 차이가 있었다 (Table 2).

단순언어장애 아동과 일반아동이 간섭 조건의 단어인출 시 보인 억제 조절 결함의 양상을 살펴보기 위해 오류유형을 분석하였다. 두 집단의 단어인출 시 오류유형을 비교한 결과, 단순언어장애 아 동은 오반응 중에 그림과 동일한 단어(방해 자극)를 산출한 비율 은 $56.3 \%$, 그림과 관련 없는 단어를 산출한 비율은 $43.7 \%$ 로 나타났 다. 일반아동은 오반응 중에 그림과 동일한 단어(방해 자극)를 산 출한 비율은 $81.8 \%$, 그림과 관련 없는 단어를 산출한 비율은 $18.2 \%$ 로 나타났다. 두 집단 모두 그림과 동일한 단어(방해 자극)를 산출 한 비율이 관련 없는 단어를 산출한 비율보다 훨씬 높았다. 그러나 그림과 관련 없는 단어를 산출한 비율은 단순언어장애 아동이 일 반아동보다 더 높게 나타났다. 두 집단의 오류 유형을 Figure 1에 제 시하였다.

Table 2. Accuracy and response time on the word retrieval under interference condition between SLI and NL

\begin{tabular}{lrrc}
\hline & SLI (N=15) & NL (N=15) & $t$ \\
\hline Word retrieval_Acc (\%) & $17.87(1.246)$ & $19.07(1.033)$ & $2.872^{*}$ \\
Word retrieval_RT (s) & $2.638(1.015)$ & $1.777(0.307)$ & $-3.142^{*}$ \\
\hline
\end{tabular}

Values are presented as mean (SD).

$\mathrm{SLI}=$ children with specific language impairment; $\mathrm{NL}=$ normal language children; Acc $=$ accuracy; $R T=$ response time ${ }^{*} p<.05$.

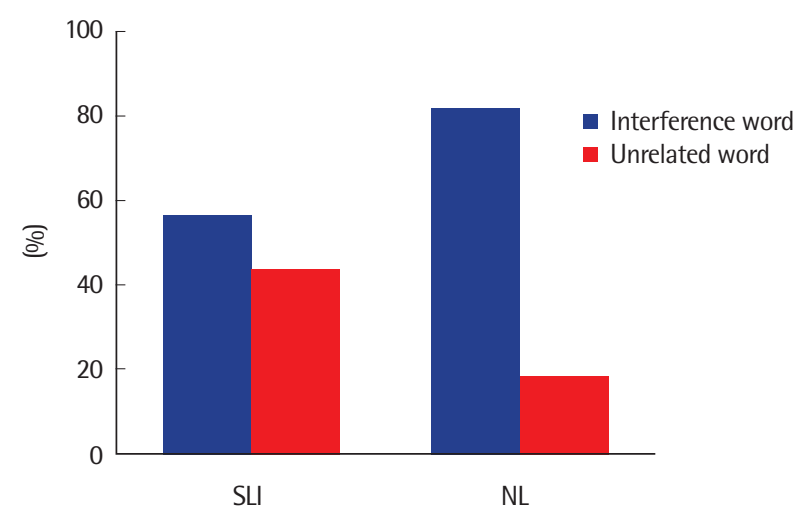

Figure 1. Comparison of error types in children with specific language impairment (SLI) and normal language (NL).

\section{집단 간(단순언어장애 아동, 일반아동) 주의력 비교}

단순언어장애 아동과 일반아동 간 주의력 과제(빠른이름대기 과제)에서 빠른이름대기의 하위 유형(숫자, 글자, 색깔, 사물)별 반 응시간을 비교한 결과, 단순언어장애 아동은 일반아동보다 색깔 빠른이름대기와 사물 빠른이름대기에서 느린 반응시간을 보였다. 독립표본 $t$-검정을 실시한 결과, 두 집단 간 색깔 빠른이름대기와 사물 빠른이름대기 반응시간에서 유의한 차이가 있었다(Table 3).

\section{집단 간(단순언어장애 아동, 일반아동) 비언어적 억제 능력과 언어적 억제 능력 비교}

단순언어장애 아동과 일반아동 간 비언어적 억제 과제(고노고 과제)와 언어적 억제 과제(스트룹 아동 색상-단어 검사)에서 정확 도를 비교한 결과, 단순언어장애 아동은 일반아동보다 낮은 수행 력을 보였다. 독립표본 $t$-검정을 실시한 결과, 두 집단 간 비언어적 억제 과제에서 유의한 차이가 없었고 언어적 억제 과제에서 유의한 차이가 있었다(Table 4).

\section{각 집단(단순언어장애 아동, 일반아동)에서 단어인출 능력과 주의력, 비언어적 억제 능력, 언어적 억제 능력 간의 상관관계}

단순언어장애 아동과 일반아동의 간섭 조건의 단어인출 과제의 정확도 및 반응시간, 주의력 과제의 반응시간, 비언어적 억제 과제의 정확도, 언어적 억제 과제의 정확도 간의 상관관계를 살펴보기 위해

Table 3. Response time on the attention task (RAN) between SLI and NL

\begin{tabular}{lllc}
\hline \multirow{2}{*}{ Attention task type } & \multicolumn{2}{c}{ Response time (s) } & \multirow{2}{*}{$t$} \\
\cline { 2 - 3 } & \multicolumn{1}{c}{$\mathrm{SLI}(\mathrm{N}=15)$} & $\mathrm{NL}(\mathrm{N}=15)$ & \\
\hline Digit & $26.33(7.835)$ & $24.07(3.555)$ & -1.020 \\
Letter & $23.33(4.880)$ & $23.20(4.586)$ & -.077 \\
Color & $51.33(11.932)$ & $43.80(6.361)$ & $-2.158^{*}$ \\
Object & $55.73(7.176)$ & $49.40(7.491)$ & $2.270^{*}$ \\
\hline
\end{tabular}

Values are presented as mean (SD).

RAN = rapid automatized naming; $S L I=$ children with specific language impairment; $\mathrm{NL}=$ normal language children .

${ }^{*} p<.05$.

Table 4. Accuracy on the nonverbal and verbal inhibition tasks between SLI and $\mathrm{NL}$

\begin{tabular}{lrrc}
\hline & SLI (N=15) & NL $(\mathrm{N}=15)$ & $t$ \\
\hline Go-no-go_Acc & $48.80(1.474)$ & $49.33(0.816)$ & 1.226 \\
Stroop_Acc & $53.73(9.750)$ & $46.33(8.209)$ & $-2.249^{*}$ \\
\hline
\end{tabular}

Values are presented as mean (SD).

$\mathrm{SLI}=$ children with specific language impairment; $\mathrm{NL}=$ normal language children; Acc $=$ accuracy.

${ }^{*} p<.05$. 
Table 5. Correlation analysis on SLI group

\begin{tabular}{|c|c|c|c|c|c|c|c|c|c|}
\hline & & $\begin{array}{c}\text { Word } \\
\text { retrieval_Acc }\end{array}$ & $\begin{array}{c}\text { Word } \\
\text { retrieval_RT }\end{array}$ & $\begin{array}{c}\text { RAN_Digit_ } \\
\text { RT }\end{array}$ & $\begin{array}{c}\text { RAN_Letter_ } \\
\text { RT }\end{array}$ & $\begin{array}{c}\text { RAN_Color_ } \\
\text { RT }\end{array}$ & $\begin{array}{c}\text { RAN_Object__ } \\
\text { RT }\end{array}$ & $\begin{array}{c}\text { Go-no-go_ } \\
\text { Acc }\end{array}$ & $\begin{array}{l}\text { Stroop } \\
\text { Acc }\end{array}$ \\
\hline \multirow[t]{2}{*}{ Word retrieval } & Word retrieval_Acc & - & & & & & & & \\
\hline & Word retrieval_RT & -.098 & - & & & & & & \\
\hline \multirow[t]{4}{*}{ Attention } & RAN_Digit_RT & .115 & .128 & - & & & & & \\
\hline & RAN_Letter_RT & .020 & .207 & .447 & - & & & & \\
\hline & RAN_Color_RT & -.151 & $.619^{*}$ & -.169 & .386 & - & & & \\
\hline & RAN_Object_RT & -.276 & $.527^{*}$ & -.231 & .150 & $.849^{* *}$ & - & & \\
\hline Nonverbal inhibition & Go-no-go_Acc & .023 & .174 & .087 & -.288 & -.256 & -.147 & - & \\
\hline Verbal inhibition & Stroop_Acc & .203 & .325 & .038 & .004 & .209 & -.031 & .323 & - \\
\hline
\end{tabular}

$S L I=$ children with specific language impairment; $R A N=$ rapid automatized naming; $A c c=$ accuracy; $R T=$ response time. ${ }^{*} p<.05,{ }^{* *} p<.01$.

Table 6. Correlation analysis on NL group

\begin{tabular}{|c|c|c|c|c|c|c|c|c|c|}
\hline & & $\begin{array}{c}\text { Word } \\
\text { retrieval_Acc }\end{array}$ & $\begin{array}{c}\text { Word } \\
\text { retrieval_RT }\end{array}$ & $\begin{array}{c}\text { RAN_Digit_ } \\
\text { RT }\end{array}$ & $\begin{array}{c}\text { RAN_Letter_ } \\
\text { RT }\end{array}$ & $\begin{array}{c}\text { RAN_Color_ } \\
\text { RT }\end{array}$ & $\begin{array}{c}\text { RAN__ } \\
\text { Object_RT }\end{array}$ & $\begin{array}{c}\text { Go-no-go_ } \\
\text { Acc }\end{array}$ & $\begin{array}{c}\text { Stroop_ } \\
\text { Acc }\end{array}$ \\
\hline \multirow[t]{2}{*}{ Word retrieval } & Word retrieval_Acc & - & & & & & & & \\
\hline & Word retrieval_RT & .365 & - & & & & & & \\
\hline \multirow[t]{4}{*}{ Attention } & RAN_Digit_RT & .349 & .251 & - & & & & & \\
\hline & RAN_Letter_RT & .434 & .377 & $.726^{* *}$ & - & & & & \\
\hline & RAN_Color_RT & -.088 & $-.520^{*}$ & -.081 & -.109 & - & & & \\
\hline & RAN_Object_RT & -.475 & .008 & .098 & .056 & $.733^{* *}$ & - & & \\
\hline Nonverbal inhibition & Go-no-go_Acc & .311 & .364 & .115 & -.038 & -.220 & -.362 & - & \\
\hline Verbal inhibition & Stroop_Acc & -.062 & .016 & .261 & .232 & .194 & .505 & -.487 & - \\
\hline
\end{tabular}

$\mathrm{NL}=$ normal language children; $\mathrm{RAN}=$ rapid automatized naming; $\mathrm{Acc}=$ accuracy; $\mathrm{RT}=$ response time. ${ }^{*} p<.05,{ }^{* *} p<.01$.

Pearson 상관분석을 실시하였다. 그 결과는 Tables 5 와 6 과 같다.

단순언어장애 아동의 단어인출 반응시간은 색깔 빠른이름대기 의 반응시간과 유의한 상관을 보였고 사물 빠른이름대기 반응시간 과 유의한 상관을 보였다. 일반아동의 단어인출 반응시간은 색깔 빠른이름대기의 반응시간과 유의한 상관을 보였다.

\section{논의 및 결론}

본 연구에서는 단순언어장애 아동과 일반아동의 간섭 조건에서 의 단어인출 능력 차이를 확인하고 단어인출 능력의 차이를 주의 력, 억제 능력과 같은 정보처리과정의 관점에서 살펴보고자 각 집 단에서 단어인출 능력과 주의력, 억제 능력 간 상관관계가 나타나 는지 알아보았다.

첫째, 간섭 조건의 단어인출 과제에서 집단 간 정확도와 반응시 간의 차이를 살펴본 결과, 단순언어장애 아동이 일반아동보다 유 의하게 정확도가 낮고 반응시간이 느렸다. 이와 관련하여 Lee (2003) 는 단순언어장애 아동이 목표 단어와 관련된 의미 정보들을 제대
로 연결하지 못해 부정확하고 느린 단어인출을 보이는 것이라고 보 고하였다. Kim (2010)은 단순언어장애 아동이 이미 습득한 단어들 을 의미적으로 정교화 되지 못한 상태로 저장하였으므로 필요한 상황에서 단어를 정확하게 인출하는 것에 어려움을 갖게 되는 것 이라고 밝혔다. 선행연구들에서 밝혀진 바와 같이 단순언어장애 아동의 정교화 되지 않은 어휘의 의미적 연결이 자신이 알고 있는 어휘를 효율적으로 인출하는데 부정적인 영향을 미친 것으로 해석 될 수 있다. 더 나아가 단순언어장애 아동은 그림이름대기와 같은 간단한 단어인출 과제뿐만 아니라, 정보처리 요구가 높은 간섭 조 건의 단어인출 과제에서 일반아동보다 많은 어려움을 보였다. Yang 등(2015)의 연구에서도 단순언어장애 아동은 방해되는 자극을 억 제하여 목표 단어로 접근하는데 어려움이 있고, 목표 단어에 도달 하기까지의 반응시간도 길었다고 하였다. 선행연구와 본 연구의 결 과를 종합하였을 때, 단순언어장애 아동은 단어인출 시 간섭 조건 의 어휘처리과정에서 목표 단어로의 접근을 방해하는 요소들을 억제하는 능력이 부족하여 목표 자극을 처리하기 위한 과정에서 오류를 보이거나 속도가 느렸다고 할 수 있다. 또한 본 연구에서 두 
집단이 간섭 조건의 단어인출 시 보인 오류를 비교한 결과, 단순언 어장애 아동의 경우 그림으로 제시되는 단어(방해 자극)뿐만 아니 라 전혀 관련 없는 단어조차도 간섭 자극으로 크게 작용하였고 이 는 목표 단어로 접근할 때 방해되는 모든 정보에 대한 저항 능력이 현저하게 부족한 것으로 해석된다. 간섭 자극에 대한 저항이 잘 이 루어지기 위해서는 목표와 관련 없는 정보를 무시하고 억제하는 능력 그리고 목표와 관련된 정보에만 집중해야 하는 선택적 주의력 이 요구되는데 이러한 능력은 특히 언어적 정보들이 동시다발적으 로 제시되는 의사소통 상황에서 중요하다고 볼 수 있다. 결과를 종 합하자면, 단순언어장애 아동은 어휘집 내에 저장되어 있는 어휘 들 간의 연결망 형성이 부족하여 간섭 자극이라 할 수 있는 목표 어 휘와 의미적 또는 음운적으로 유사한 다른 어휘 정보로부터 쉽게 방해를 받고 이로 인해 습득한 단어를 인출하는 과정에서 불필요 한 정보를 억제하는데 어려움을 보인다. 따라서 단순언어장애 아 동을 대상으로 어휘집 속에 있는 어휘들 간의 긴밀한 연결을 지을 수 있는 중재가 실시된다면 간섭 자극에 대한 억제가 효율적으로 이루어질 수 있을 것이다. 이로 인해 목표 어휘로의 접근이 정확하 고 빠르게 이루어져 실제 의사소통 상황에서 메시지를 효율적으로 전달하는데 도움이 될 것이다.

둘째, 빠른이름대기 과제에서 집단 간 반응시간의 차이를 살펴본 결과, 색깔 빠른이름대기와 사물 빠른이름대기에서 단순언어장애 아동이 일반아동보다 유의하게 반응시간이 느렸다. Hogan-Brown 등(2014)은 색깔 및 사물 빠른이름대기를 덜 자동화된 과제로 분 류하였는데, 이러한 자동화를 반응시간의 결과로 비춰본다면 본 연구에서 단순언어장애 아동은 덜 자동화된 과제인 색깔과 사물 빠른이름대기의 반응시간에서 일반아동과 유의한 차이가 있었다. 단순언어장애 아동은 색깔 및 사물 빠른이름대기에서 요구되는 그 림 자극에 대한 의미적 처리 과정에서 어려움이 있었으므로 목표 단어에 접근하는데 오랜 시간이 소요된 것으로 볼 수 있다. Van den Bos, Zijlstra와 Lutje Spelberg (2002)는 빠른이름대기 유형 중 에 특히, 색깔 빠른이름대기와 사물 빠른이름대기가 주의력 문제 와 밀접한 관련이 있다고 밝혔다. 이를 통해 단순언어장애 아동은 하나의 그림 자극을 말하고 나서 빨리 다음 자극으로 주의를 기울 이는 주의 전환 능력과 과제 전반에 걸친 지속적 주의력이 낮아 느 린 언어적 처리 속도를 보였을 것으로 유추된다. 따라서 단순언어 장애 아동을 중재할 때 언어적 접근뿐만 아니라 주의력과 관련된 인지적 측면에서의 접근 방법이 고려될 필요가 있다.

셋째, 비언어적 억제 과제(고노고 과제)와 언어적 억제 과제(스트 룹 아동 색상-단어 검사)에서 집단 간 정확도의 차이를 살펴본 결 과, 먼저, 고노고 과제에서 집단 간 수행력 차이가 유의하지 않아 단
순언어장애 아동의 비언어적 억제 능력은 양호한 것으로 나타났다. 즉, 이들은 자동적으로 반응하는 행동을 억누르기 위한 행동적 반 응 억제 능력에서는 일반아동과 차이가 없었다. 그러나 스트룹 아 동 색상-단어 검사에서는 단순언어장애 아동의 수행력이 일반아 동에 비해 유의하게 낮았다. 다시 말해서 단순언어장애 아동은 자 동화된 단어 읽기 반응을 억제하고 덜 우세한 반응인 색상의 이름 을 말해야 하는 언어적 처리 과정에서 어려움을 보인 것이다. Henry, Messer와 Nash (2012)는 단순언어장애 아동을 대상으로 언어 적 억제(verbal inhibition) 과제와 행동적 억제(motor inhibition) 과제를 실시하였다. 연구 결과, 단순언어장애 아동은 비언어적 억 제 능력과 언어적 억제 능력 모두 약화된 것으로 나타났다. 이러한 선행연구 결과는 본 연구에서 단순언어장애 아동의 언어적 억제 능력이 일반아동에 비해 유의하게 낮다는 결과와 일치한다. 그러 나 비언어적 억제 능력에 대한 결과는 선행연구와 차이가 있다. 이 러한 차이는 비언어적 억제 과제에서 제시된 자극의 차이로 설명할 수 있는데 Henry 등(2012)은 방해 자극을 청각적 자극으로 제시하 였으나 본 연구에서는 방해 자극을 시각적 자극으로 제시하였다. 본 연구와 동일하게 시각적인 자극을 제시하여 억제 능력을 살펴본 Dodwell과 Bavin (2008)은 단순언어장애 아동을 대상으로 고노 고 과제를 실시하였다. 그 결과, 단순언어장애 아동이 시각적 자극 에 대한 억제 능력은 양호한 것으로 보고하였다. 따라서 단순언어 장애 아동은 청각적 억제보다 시각적 억제 과정에서 효율적인 처리 가 일어난 것을 확인할 수 있다. 이는 단순언어장애 아동이 청각적 자극보다 시각적 자극에 더 높은 주의집중력을 보인다는 선행연구 를 뒷받침하는 결과로 볼 수 있다(Spaulding et al., 2008). 한편, 부 족한 언어적 억제 능력과 관련하여 Hong과 Yim (2014)은 10-12세 단순언어장애 아동의 중앙집행장치 수행력을 살펴보고자 중앙처 리장치 과제로 스트룹 아동 색상-단어 검사를 실시하였다. 그 결과, 단순언어장애 아동이 일반아동보다 언어적 억제 능력이 낮은 것으 로 나타났다. 즉, 이들은 불필요한 글자 자극에 대한 정보처리는 억 제하고 필요한 색깔 자극에 대한 정보에만 주의를 기울여 처리하 는데 어려움을 보였다. 이러한 결과는 본 연구에서 실시한 스트룹 아동 색상-단어 검사에서 나타난 결과와 일치한다. 억제 능력에 대 한 다양한 선행연구 결과를 바탕으로 단순언어장애 아동의 부족 한 억제 조절 능력이 자동적인 행동 반응을 통제해야 하는 비언어 적 처리보다 언어적인 정보를 담고 있는 자극을 억제해야 하는 언 어적 처리에 더 많은 영향을 받을 가능성이 있는 것으로 보인다. 따 라서 언어적 억제 능력에서 취약함을 보이는 단순언어장애 아동에 게 동시적으로 입력되는 언어 정보들 중에 먼저 필요한 정보와 불 필요한 정보를 구분하게 하고 필요한 정보만을 처리하기 위해 불필 
요한 정보에는 집중하지 않게 하는 처리 과정에 대한 중재가 들어 간다면 처리 과정이 원활하게 이루어져 언어적 정보를 더욱 더 정 확하고 빠르게 처리할 수 있을 것이다. 또한 비언어적(행동적) 억제 의 경우 단순언어장애 아동에게 과제를 제시할 때 시각보다는 청 각자극 중심으로 구성해야 할 필요가 있다.

넷째, 각 집단에서 단어인출 능력, 주의력, 비언어적 억제 능력, 언 어적 억제 능력 간 상관관계를 살펴보았다. 단순언어장애 아동의 단어인출 과제의 반응시간은 색깔 및 사물 빠른이름대기 과제의 반응시간과 유의한 상관을 보였다. 일반아동은 단어인출 과제의 반응시간이 색깔 빠른이름대기 과제의 반응시간과 유의한 상관을 보였다. 빠른이름대기 과제의 하위 과제 중 색깔 및 사물 빠른이름 대기 과제는 그림 자극에 대한 언어적 처리를 요구하므로 숫자 및 글자 빠른이름대기보다 덜 자동화된 과제로 인지적 부담이 높아 처리 속도가 늦어진다고 볼 수 있다(Hogan-Brown et al., 2014). 또 한, 간섭 조건의 단어인출 과정은 목표 어휘로의 빠른 접근과 함께 간섭 단어의 인출을 억제하고 목표 어휘가 최종적으로 표현될 때 까지 주의력 유지가 요구된다. 이러한 인지적 부담은 빠른이름대기 과제 중 색깔 및 사물 하위 과제에 필수적으로 작용한다. 즉, 자극 간의 경쟁에서 목표 자극에만 주의를 기울여 해당 자극과 관련된 정보들을 빠르게 처리한다는 점에서 색깔 및 사물 빠른이름대기 과제와 간섭 조건의 단어인출 과제는 공통된 특성을 가진다. 그리 하여 단순언어장애 아동과 일반아동은 인지적 처리를 요구하는 과제의 반응시간 간에 유의한 상관을 보인 것으로 유추된다.

본 연구를 통해 단순언어장애 아동은 필요한 자극에만 주의하 여 정보를 받아들이고 방해 자극을 제거해야 하는 간섭 조건의 단 어인출 과제에서 일반아동보다 부족한 수행을 보였다. 또한 단순언 어장애 아동이 언어적 처리가 더 요구되는 주의력 과제와 억제 과 제에서 일반아동보다 어려움이 있음을 확인할 수 있었다. 이는 단 순언어장애 아동은 일반아동과 비교하여 단어인출과 관련된 언어 적 처리 과정 및 방식에서 차이가 있음을 시사한다. 그러나 본 연구 에서는 단순언어장애 아동과 생활연령이 일치하는 아동으로 두 집 단으로만 나누어 살펴보았는데 생활연령이 일치하는 아동뿐만 아 니라 언어연령이 일치하는 아동도 단순언어장애 아동과 함께 살펴 본다면 단순언어장애 아동이 보이는 언어적 처리에 대한 양상과 주 의력, 억제 능력의 결함을 더 자세히 살펴볼 수 있을 것이다. 또한 간 섭 조건에서의 단어인출 과제에서 단순언어장애 아동이 오반응을 보였을 때, 어떤 단어로 오류를 보였는지 오류특성에 대한 분석과 오반응한 시간을 함께 측정하여 정반응한 시간과 어떠한 차이가 있 는지 알아보는 질적 분석을 통해 살펴보는 것도 의미가 있을 것이다.

\section{REFERENCES}

Baddeley, A. D. (1983). Working memory. Philosophical Transactions of the Royal Society of London B Biological Sciences, 302(1110), 311-324.

Baddeley, A. D. (1986). Working memory. Oxford: Clarendon Press.

Bishop, D. V., \& Norbury, C. F. (2005). Executive functions in children with communication impairments, in relation to autistic symptomatology I: Generativity. Autism, 9(1), 7-27.

Choi, H. S. (2014). A quantitative study on vocabularies contained in elementary school Korean textbooks: centering on the 1st year Korean textbooks revised in 2009 (Master's thesis). Kunsan National University, Gunsan, Korea.

Denckla, M. B., \& Rudel, R. G. (1976). Rapid 'automatized' naming (RAN): dyslexia differentiated from other learning disabilities. Neuropsychologia, 14(4), 471-479.

Dodwell, K., \& Bavin, E. L. (2008). Children with specific language impairment: an investigation of their narratives and memory. International Journal of Language \& Communication Disorders, 43(2), 201-218.

Fried-Oken, M. B. (1984). The development of naming skills in normal and language deficient children (Doctoral dissertation). Boston University, Boston, MA, USA.

German, D. J. (1994). Word finding difficulties in children and adolescents. In G. P. Wallach \& K. G. Butler (Eds.), Language learning disabilities in school-age children and adolescents: some principles and applications (pp. 323-347). New York, NY: Pearson.

German, D. J. (2000). Test of Word Finding. Austin, TX: Pro-Ed.

Gleason, J. B. (2005). The development of language (6th ed.). Boston, MA: Allyn \& Bacon.

Henry, L. A., Messer, D. J., \& Nash, G. (2012). Executive functioning in children with specific language impairment. Journal of Child Psychology and Psychiatry, 53(1), 37-45.

Henry, L., \& Winfield, J. (2010). Working memory and educational achievement in children with intellectual disabilities. Journal of Intellectual Disability Research, 54(4), 354-365.

Hogan-Brown, A. L., Hoedemaker, R. S., Gordon, P. C., \& Losh, M. (2014). Eye-voice span during rapid automatized naming: evidence of reduced automaticity in individuals with autism spectrum disorder and their siblings. Journal of Neurodevelopmental Disorders, 6(1), 33.

Hong, H., \& Yim, D. (2014). Working memory subsystems and receptive vocabulary in children with specific language impairment. Journal of Speech 
\& Hearing Disorders, 23(2), 35-44.

Hwang, M., Lim, J. A., Choi, K., Ko, S., Choi, S., Kim, J., \& Jeon, M. Y. (2016). Inhibition of interference during word reading in children with attention deficit hyperactive disorder. Communication Sciences \& Disorders, 21(1), 121-130.

Im-Bolter, N., Johnson, J., \& Pascual-Leone, J. (2006). Processing limitations in children with specific language impairment: the role of executive function. Child Development, 77(6), 1822-1841.

Jin, S. Y., Lee, M. J., \& Hong, C. H. (2007). Diagnostic discrimination of sluggish cognitive tempo and attention task in the assessment of attention-deficit/hyperactivity disorder subtypes. Korean Journal of Clinical Psychology, 26(2), 497-510.

Kail, R., \& Salthouse, T. A. (1994). Processing speed as a mental capacity. Acta Psychologica, 86(2-3), 199-225.

Kim, H. S. (2009). Research of the vocabulary of elementary school textbook. Seoul: National Institute of Korean Language.

Kim, J. M. (2005). Language development of school-aged children. Proceedings of the Korean Academy of Speech-Language Pathology and Audiology (KASLA) Winter Workshop, Seoul Korea.

Kim, M. J. (2010). Comparative study on the characteristics difference of wordnaming and semantic feature according to word frequency between general children and children with specific language impairment (Master's thesis). Dankook University, Seoul, Korea.

Kim, O. H., Choi, S., \& Hwang, M. (2016). Semantic interference effect in picture-word naming tasks between youth and elderly. Communication Sciences \& Disorders, 21(3), 462-471.

Kim, Y. T., Hong, G. H., Kim, K. H., Jang, H. S., \& Lee, J. Y. (2009). Receptive \& expressive vocabulary test (REVT). Seoul: Seoul Community Rehabilitation Center.

Lahey, M., \& Edwards, J. (1999). Naming errors of children with specific language impairment. Journal of Speech, Language, and Hearing Research, 42(1), 195-205.

Lee, E. Y., \& Ha, J. W. (2015). Semantic representation in children with specific language impairment. Communication Sciences \& Disorders, 20(2), 277-289.

Lee, Y. K. (2003). Word-finding abilities in children with specific language impairment (Doctoral dissertation). Ewha Womans University, Seoul, Korea.

Lee, Y. K., \& Kim, Y. T. (2002). Word-finding abilities in children with specific language impairment. Korean Journal of Communication \& Disorders, $7(1), 65-80$.
Lee, Y. K., \& Kim, Y. T. (2003). Effects of semantic priming on word-finding ability of children with specific language impairment. Korean Journal of Communication \& Disorders, 8(3), 22-39.

Leonard, L. B. (1998). Language, speech, and communication: children with specific language impairment. Cambridge, MA: MIT Press.

Levelt, W. J., Roelofs, A., \& Meyer, A. S. (1999). A theory of lexical access in speech production. Behavioral and Brain Sciences, 22(1), 1-38.

Long, S. H., \& Long, S. T. (2005). Language and children with learning disabilities. In V. A. Reed (Ed.), An introduction to children with language disorders. Boston, MA: Pearson.

McGregor, K. K. (1994). Use of phonological information in a word-finding treatment for children. Journal of Speech, Language, and Hearing Research, 37(6), 1381-1393.

McGregor, K. K., \& Leonard, L. B. (1989). Facilitating word-finding skills of language-impaired children. Journal of Speech and Hearing Disorders, 54(2), 141-147.

Pae, S. Y. (2005). Language assessment of school aged children. Proceedings of the Korean Academy of Speech-Language Pathology and Audiology (KASLA) Winter Workshop, Seoul, Korea.

Park, H. (2014). Korean version of Comprehensive Test of Nonverbal Intelligence Second Edition (K-CTONI-2). Seoul: Mindpress.

Park, H. J. (2009). The effects of early screening and intervention for children at-risk of reading underachievement (Doctoral dissertation). Ewha Womans University, Seoul, Korea.

Paul, R. (2003). Language disorders from infancy through adolescence (2nd ed.). St. Louis, MO: Mosby.

Paul, R. (2007). Language disorders from infancy through adolescence (3rd ed.). St. Louis, MO: Mosby.

Pisoni, D. B., Kronenberger, W., Roman, A., \& Geers, A. (2011). Measures in digit span and verbal rehearsal speed in deaf children following more than 10 years of cochlear implant use. Ear and Hearing, 32(1 Suppl), 60S-74S.

Plaza, M., \& Cohen, H. (2005). Influence of auditory-verbal, visual-verbal, visual, and visual-visual processing speed on reading and spelling at the end of Grade 1. Brain and Cognition, 57(2), 189-194.

Seiger-Gardner, L., \& Schwartz, R. G. (2008). Lexical access in children with and without specific language impairment: a cross-modal picture-word interference study. International Journal of Language \& Communication Disorders, 43(5), 528-551.

Shin, M. S., \& Park, M. J. (2007). Stroop Color and Word Test. Seoul: Hakjisa. Spaulding, T. J. (2010). Investigating mechanisms of suppression in preschool 
children with specific language impairment. Journal of Speech, Language, and Hearing Research, 53(3), 725-738.

Spaulding, T. J., Plante, E., \& Vance, R. (2008). Sustained selective attention skills of preschool children with specific language impairment: evidence for separate attentional capacities. Journal of Speech, Language, and Hearing Research, 51(1), 16-34.

Stevens, C., Sanders, L., \& Neville, H. (2006). Neurophysiological evidence for selective auditory attention deficits in children with specific language impairment. Brain Research, 1111(1), 143-152.

Swisher, L., Plante, E., \& Lowell, S. (1994). Nonlinguistic deficits of children with language disorders complicate the interpretation of their nonverbal IQ scores. Language, Speech, and Hearing Services in Schools, 25(4), 235240.

Van den Bos, K. P., Zijlstra, B. J., \& Lutje Spelberg, H. C. (2002). Life-span data on continuous-naming speeds of numbers, letters, colors, and pictured objects, and word-reading speed. Scientific Studies of Reading, 6(1),
25-49.

Visto, J. C., Cranford, J. L., \& Scudder, R. (1996). Dynamic temporal processing of nonspeech acoustic information by children with specific language impairment. Journal of Speech, Language, and Hearing Research, 39(3), 510517.

Waber, D. P., Wolff, P. H., Forbes, P. W., \& Weiler, M. D. (2000). Rapid automatized naming in children referred for evaluation of heterogeneous learning problems: how specific are naming speed deficits to reading disability? Child Neuropsychology, 6(4), 251-261.

Wilson, S. P., \& Kipp, K. (1998). The development of efficient inhibition: evidence from directed-forgetting tasks. Developmental Review, 18(1), 86-123.

Wolf, M., \& Bowers, P. G. (1999). The double-deficit hypothesis for the developmental dyslexias. Journal of Educational Psychology, 91(3), 415-438.

Yang, Y., Yim, D., \& Bae, K. (2015). Predictors of word learning in children with specific language impairment. Communication Sciences \& Disorders, 20(1), 1-12. 
Appendix 1. 간섭 조건의 단어인출 과제에서 사용된 단어 목록

\begin{tabular}{|c|c|c|c|c|}
\hline & & $\begin{array}{l}\text { 간섭 단어(그림으 } \\
\text { 로 제시되는 단어) }\end{array}$ & $\begin{array}{c}\text { 목표 단어(그림과 } \\
\text { 반대되는 단어) }\end{array}$ & $\begin{array}{c}\text { 비관련 단어(그림과 } \\
\text { 관련 없는 단어) }\end{array}$ \\
\hline \multirow[t]{4}{*}{ 연습 문항 } & 1 & 의사 & 환자 & 사장 \\
\hline & 2 & 바깥 & 안 & 중간 \\
\hline & 3 & 거인 & 난쟁이 & 요정 \\
\hline & 4 & 엑스 & 오 & 세모 \\
\hline \multirow[t]{20}{*}{ 본 문항 } & 1 & 위 & 아래 & 어디 \\
\hline & 2 & 달 & 해 & 눈 \\
\hline & 3 & 손 & 발 & 목 \\
\hline & 4 & 흐림 & 맑음 & 바람 \\
\hline & 5 & 아빠 & 엄마 & 어부 \\
\hline & 6 & 불 & 물 & 돌 \\
\hline & 7 & 학생 & 선생님 & 삼촌 \\
\hline & 8 & 책상 & 의자 & 전화 \\
\hline & 9 & 바다 & 산 & 분수 \\
\hline & 10 & 다리 & 팔 & 날개 \\
\hline & 11 & 하양 & 검정 & 종이 \\
\hline & 12 & 치마 & 바지 & 팔찌 \\
\hline & 13 & 공주 & 왕자 & 거인 \\
\hline & 14 & 겨울 & 여름 & 내일 \\
\hline & 15 & 연필 & 지우개 & 가방 \\
\hline & 16 & 거북이 & 토끼 & 도깨비 \\
\hline & 17 & 어린이 & 어른 & 이모 \\
\hline & 18 & 천사 & 악마 & 손님 \\
\hline & 19 & 하늘 & 땅 & 터널 \\
\hline & 20 & 시골 & 도시 & 거실 \\
\hline
\end{tabular}

Appendix 2. 간섭 조건의 단어인출 과제 제시 화면의 예

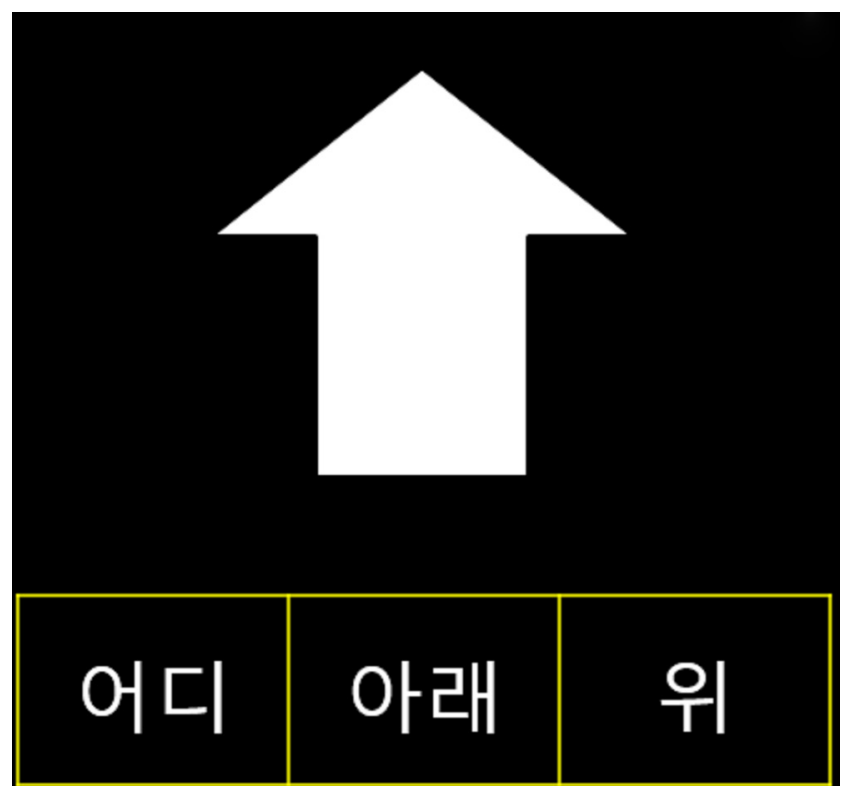




\title{
국문초록
}

\author{
초등 3-4학년 단순언어장애 아동의 간섭 조건에서의 단어인출 능력과 주의력 및 억제 능력 \\ 장유경 $\cdot$ 김수련 ${ }^{2}$ \\ 1부산가톨릭대학교 대학원 언어청각치료학과, ${ }^{2}$ 단국대학교 대학원 언어병리학과
}

배경 및 목적: 단순언어장애 아동의 언어적 처리 부담이 높은 간섭 조건에서의 단어인출 능력을 살펴보고 저하된 단어인출 능력을 주 의력 및 억제 능력의 결함으로 설명할 수 있는지 알아보고자 하였다. 방법: 연구대상은 초등 3-4학년 단순언어장애 아동 15 명, 학년을 일치시킨 일반아동 15 명, 총 30 명이었다. 연구 과제는 간섭 조건의 단어인출 과제, 주의력 과제(빠른이름대기 과제), 비언어적 억제 과제 (고노고 과제), 언어적 억제 과제(스트룹 아동 색상-단어 검사)를 실시하였다. 두 집단의 간섭 조건에서의 단어인출 정확도, 반응시간을 비교하였고 주의력, 비언어적 및 언어적 억제 능력을 비교하였다. 결과: 단순언어장애 아동은 단어인출에 걸리는 반응시간이 유의하게 길었다. 오류를 분석한 결과, 단순언어장애 아동은 방해 자극뿐만 아니라 관련 없는 단어조차 억제하는데 어려움을 보였다. 또한, 높은 수준의 주의력과 언어 처리가 요구되는 색깔, 사물 빠른이름대기와 언어적 억제 능력이 일반아동보다 유의하게 낮았다. 단순언어장애 아동의 단어인출 반응시간은 색깔, 사물 빠른이름대기의 반응시간과 유의한 상관을 보였다. 논의 및 결론: 단순언어장애 아동이 의미 처리 과정에서 목표 자극에 대한 주의력과 간섭 자극을 억제하는 능력이 일반아동보다 저하되었음을 확인하였다. 따라서 단순언어장 애 아동의 어휘 학습 및 단어인출 능력을 중재할 때 인지적 측면에서의 접근 방법이 고려될 필요가 있다.

핵심어: 학령기, 단순언어장애, 간섭 조건, 단어인출, 주의력, 억제 능력

본 연구는 제 1 저자의 석사학위논문을 수정 및 보완하였음.

\section{참고문헌}

김미자(2010). 정상 아동과 단순언어장애 아동의 낱말 빈도에 따른 이름대기와 의미자질 특성 비교 연구. 단국대학교 대학원 석사학위논문. 김영태, 홍경훈, 김경희, 장혜성, 이주연(2009). 수용·표현어휘력검사(REVT). 서울: 서울장애인종합복지관.

김오현, 최소영, 황민아(2016). 그림 이름대기에서 나타난 청년층과 노년층의 의미간섭효과. Communication Sciences \& Disorders, 21(3), 462-471. 김정미(2005). 학령기 아동 언어발달. 2005년도 언어치료 겨울연수회자료집.

김한샘(2009). 초등학교 교과서 어휘 조사 연구. 서울: 국립국어원.

박현정(2009). 읽기학습부진 위험군 아동의 조기선별 및 조기개입의 효과 검증. 이화여자대학교 대학원 박사학위논문.

박혜원(2014). 한국 비언어지능검사 2판(K-CTONI-2). 서울: 마인드프레스.

배소영(2005). 학령기 아동의 언어평가. 2005년도 언어치료 겨울연수회자료집.

신민섭, 박민주(2007). 스트릅 아동 색상-단어 검사. 서울: 학지사.

양윤희, 임동선, 배경란(2015). 학령기 단순언어장애 아동의 어휘학습 예측요인: 의미점화 및 간섭 효과. Communication Sciences \& Disorders,

20(1), 1-12.

이윤경(2003). 단순언어장애 아동의 낱말찾기 특성: 어휘산출과정을 중심으로. 이화여자대학교 대학원 박사학위논문.

이윤경, 김영태(2002). 단순언어장애 아동의 낱말찾기 특성. 언어청각장애연구, 7(1), 65-80.

이윤경, 김영태(2003). 단순언어장애 아동들의 낱말산출 능력: 명사와 동사를 중심으로. 언어청각장애연구, 8(1), 1-19.

이은영, 하지완(2015). 단순언어장애 아동과 일반 아동의 의미표상 비교. Communication Sciences \& Disorders, 20(2), 277-289.

진선영, 이명주, 홍창희(2007). ADHD 하위 유형의 평가에서 굼뜬 인지적 템포와 주의 과제의 진단적 유용성. 한국심리학회지: 임상, 26(2), 497-510. 최해성(2014). 초등학교 국어 교과서 어휘의 계량적 연구: 2009 개정 1 학년 국어 교과서를 중심으로. 군산대학교 대학원 석사학위논문.

홍현주, 임동선(2014). 단순언어장애 아동의 작업기억 하위체계와수용어휘능력 간의 관계. 언어치료연구, 23(2), 35-44.

황민아, 임종아, 최경순, 고선희, 최소영, 김주형, 전미영(2016). 주의력결핍 과잉행동장애 아동의 단어재인에서 간섭자극 억제 능력. Communication

Sciences \& Disorders, 21(1), 121-130.

\section{ORCID}

장유경(제1저자, https://orcid.org/0000-0003-0530-8701); 김수련(교신저자, https://orcid.org/0000-0003-3150-7798) 